\title{
Study on the Preparation of Si-Al Alloy by Carbon Reduction Coal Fly Ash
}

\author{
Zhiling Bai ${ }^{1, a}$, Bingke Qin ${ }^{1,2, b}$, Minglei Lian ${ }^{1, c}$ \\ ${ }^{1}$ School of Chemistry and Materials Engineering, Liupanshui Normal University, Liupanshui, China \\ ${ }^{2}$ College of Materials and Metallurgy, Guizhou University, Guiyang, China \\ azhilingbai@126.com, ${ }^{b}$ qinbingke@126.com, ${ }^{c}$ lianming12@126.com
}

Keywords: coal fly ash; carbon thermal reduction; carbon content; reduction temperature; Si-Al alloy

Abstract. In this paper, the effects of reduction temperature and carbon content on the preparation of silicon-aluminum alloy by carbothermal reduction coal fly ash were studied. The reduction products were characterized by XRD. The results showed that when carbon content was 1.15 or 1.3 times and reduction temperature was $1900^{\circ} \mathrm{C}, \mathrm{Al}_{4} \mathrm{C}_{3}$ was formed in the reduction products and $\mathrm{Al}_{2} \mathrm{O}_{3}$ was not completely reacted; when carbon content was 1.15 times and reduction temperature was $2000^{\circ} \mathrm{C}, \mathrm{Al}_{6} \mathrm{Fe}, \mathrm{SiC}, \mathrm{Al}_{8} \mathrm{Fe}_{2} \mathrm{Si}, \mathrm{Si}$ and $\mathrm{Al}$ were produced by carbon reduction coal fly ash. When carbon content was 1.3 times and reduction temperature was $2000^{\circ} \mathrm{C}$, reduction product had many impurities. When carbon content was 1.15 times and reduction temperature was $2000^{\circ} \mathrm{C}$, siliconaluminum alloy was obtained, impurities of the reduction products were less, the effect of carbon reduction coal fly ash on the preparation of silicon-aluminum alloy was the best.

\section{Introduction}

Coal fly ash is the main solid waste discharged from coal-fired power plants. It is also one of the industrial wastes with large displacement. With the development of the power industry, the amount of coal fly ash discharged from coal-fired power plants has increased year by year. The world energy crisis, environmental pollution and the depletion of mineral resources have stimulated the research and development of coal fly ash. Coal fly ash has become a raw material in the building materials, chemical industry and materials industry, which is rich in resource, low in price and beneficial to the industry. The comprehensive utilization of coal fly ash is an emerging industry with high technical content, broad market prospects, environmental protection and resource reuse. Coal fly ash contains a large amount of $\mathrm{Al}_{2} \mathrm{O}_{3}$ and $\mathrm{SiO}_{2}$. The use of coal fly ash to extract siliconaluminum alloy can not only control the pollution problem of coal fly ash, improve the environment, but also open up a new source of silicon-aluminum alloy for the metallurgical industry [1].

Silicon-aluminum alloy has the advantages of light and tough, high strength, good heat and abrasion resistance, good casting performance and so on.It is suitable for automobile manufacturing, aviation industry, electrical industry and shipbuilding industry[2,3]. Silicon-aluminum alloy has high reducibility at high temperature. It can be used to smelt high melting point metals. In addition, silicon-aluminum alloy can be used as a high quality steelmaking deoxidizer and the main raw material of aluminum foam. The traditional method for producing silicon-aluminum alloy has high cost[4]. The preparation of silicon-aluminum alloy by carbon thermal reduction coal fly ash can reduce the production cost of silicon-aluminum alloy, enlarge the utilization rate of coal fly ash, make coal fly ash waste become a treasure and obtain high added value utilization.

\section{Research methods}

In this experiment, coal fly ash of Yema Power Plant in Liupanshui was used as raw material, charcoal was used as the reducing agent, wood calcium was used as the binder. The main chemical components of coal fly ash are $\mathrm{Al}_{2} \mathrm{O}_{3}$ and $\mathrm{SiO}_{2}$, as shown in Table 1. The calculated theoretical carbon content and the mass ratio of coal fly ash was 33:100. Considering the carbon loss during the experiment and the effect of carbon content on the preparation of silicon-aluminum alloy from coal 
fly ash. The carbon content of this study was 1.15 or 1.3 times of the theoretical carbon content, respectively. Before the ingredients, coal fly ash was placed in a drying oven and dried at $110^{\circ} \mathrm{C}$ for 2 hours to remove moisture. The ingredients were coal fly ash and charcoal. The wood calcium was taken $8 \%$ of the quality of coal fly ash and charcoal, water was taken $10 \%$ of the quality of coal fly ash and charcoal. The weighed ingredients were put into the mortar and mixed evenly. The uniformly mixed raw materials were weighed into $34 \mathrm{~g}$ each time and placed in a self-made mold. Samples with a diameter of $24 \mathrm{~mm}$ and a height of $20 \mathrm{~mm}$ were produced under a pressure of $10 \mathrm{Mpa}$ using a tableting machine. The prepared sample were placed in a constant temperature drying oven at $120^{\circ} \mathrm{C}$ for drying.

Table1 Chemical composition of Coal fly ash (wt.\%)

\begin{tabular}{ccccccccc}
\hline Composition & $\mathrm{Al}_{2} \mathrm{O}_{3}$ & $\mathrm{SiO}_{2}$ & $\mathrm{CaO}$ & $\mathrm{TiO}_{2}$ & $\mathrm{Fe}_{2} \mathrm{O}_{3}$ & $\mathrm{MgO}$ & $\mathrm{MnO}$ & $\mathrm{LOI}$ \\
Content(wt.\%) & 24 & 46.2 & 4.25 & 3.31 & 16.1 & 1.51 & 0.15 & 4.48 \\
\hline
\end{tabular}

This experiment uses a high-frequency induction melting furnace of type HT-25AB. When using it, first open the cooling water system, let the water pass the instrument for about five minutes, ensure that the water can circulate through the instrument, then open the control system and turn on the infrared thermometer. After setting the required temperature, adjust the current value. When the thermometer reaches the set temperature, the prepared sample is quickly placed in the graphite crucible, covered with a cap with a hole in the middle, the melting time is 30 minutes, the product to be reduced is naturally cooled to room temperature. The phase composition of the reduced product is characterized by a TD-2500 type x-ray diffractometer.

\section{Results and discussion}

Effect of reduction temperature on preparation of silicon-aluminum alloy from carbon reduction coal fly Ash.

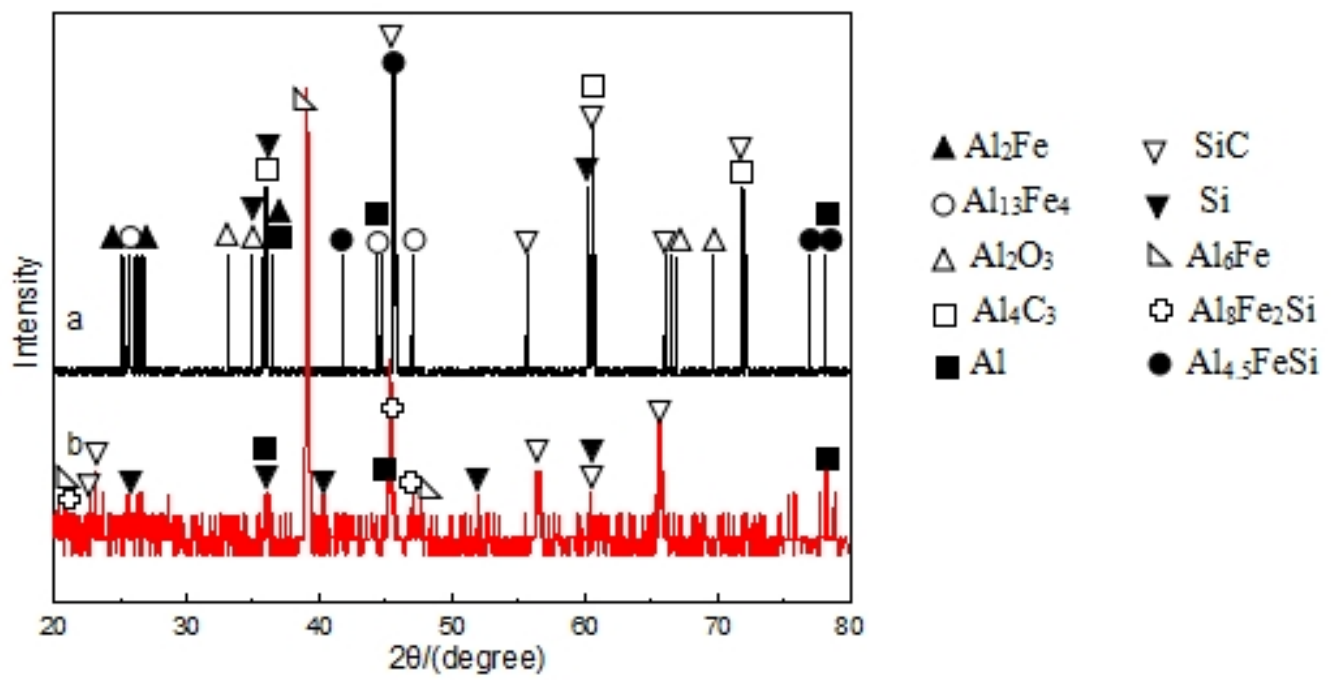

Fig.1 XRD pattern of the reduced product a $1.15 \mathrm{C}, 1900^{\circ} \mathrm{C}$; b $1.15 \mathrm{C}, 2000^{\circ} \mathrm{C}$

It can be seen from a in Fig. 1 that under the conditions of carbon content 1.15 times, reduction temperature $1900^{\circ} \mathrm{C}$ and heat preservation for 30 minutes, the products of carbon reduction coal fly ash were $\mathrm{Al}_{4} \mathrm{C}_{3}, \mathrm{Al}_{2} \mathrm{Fe}, \mathrm{Al}_{13} \mathrm{Fe}_{4}, \mathrm{Al}_{4.5} \mathrm{FeSi}, \mathrm{SiC}, \mathrm{Si}, \mathrm{Al}$ and unreacted $\mathrm{Al}_{2} \mathrm{O}_{3}$. When the reduction temperature was $1900^{\circ} \mathrm{C}, \mathrm{Al}_{2} \mathrm{O}_{3}$ in the coal fly ash was not completely reacted. It may be due to the reaction of charcoal and $\mathrm{SiO}_{2}$ in the coal fly ash to form silicon carbide. The partial carbon was consumed and $\mathrm{Al}_{2} \mathrm{O}_{3}$ was not fully reacted complete[5]. $\mathrm{Al}_{4} \mathrm{C}_{3}, \mathrm{SiC}$ were formed in the reduction products, which reduced the formation rate of aluminum and silicon. It can be seen from $\mathrm{b}$ in Fig. 1 that under the conditions of carbon content 1.15 times, reduction temperature $2000^{\circ} \mathrm{C}$ and heat 
preservation for 30 minutes, $\mathrm{Al}_{6} \mathrm{Fe}, \mathrm{Al}_{8} \mathrm{Fe}_{2} \mathrm{Si}, \mathrm{SiC}, \mathrm{Si}$ and $\mathrm{Al}$ were formed by carbon reduction coal fly ash. Compared a and b in Fig.1, the carbon content was 1.15 times and the temperature was kept for 30 minutes, the reduction effect of carbon reduction coal fly ash was better at the reduction temperature of $2000^{\circ} \mathrm{C}$ than the reduction temperature of $1900^{\circ} \mathrm{C}$.

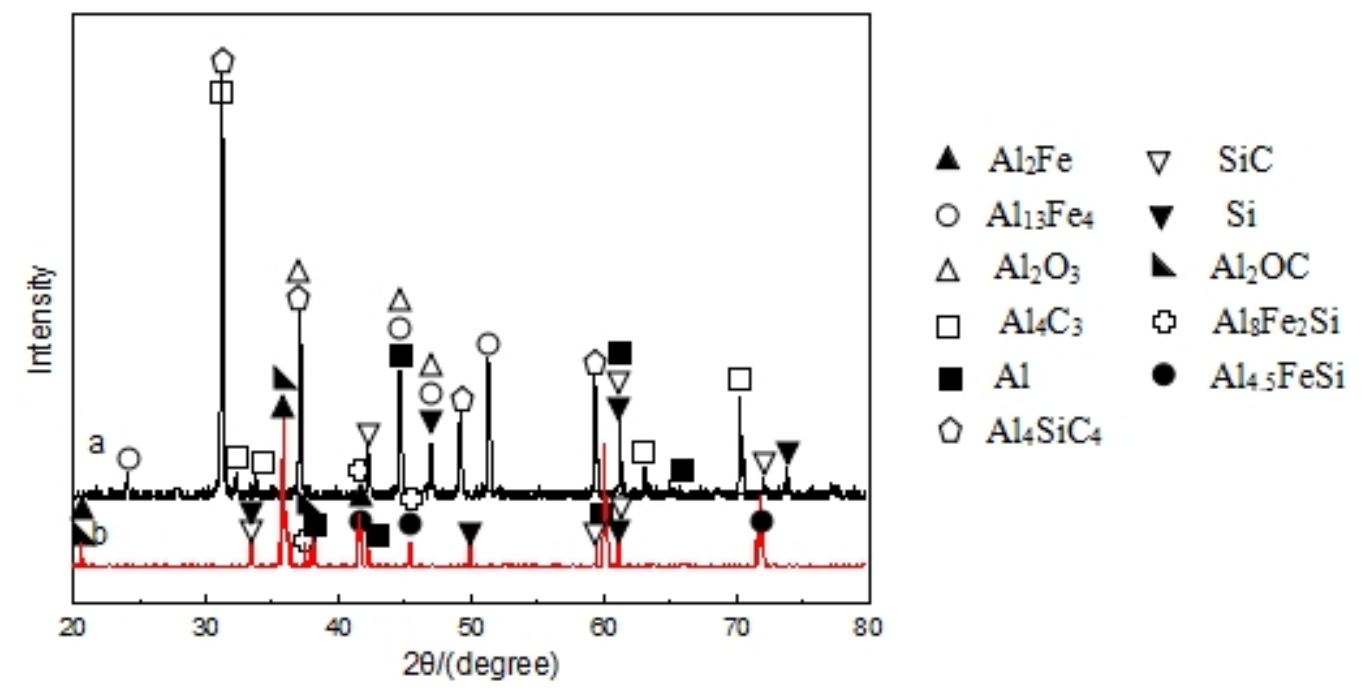

Fig. 2 XRD pattern of the reduced product a $1.3 \mathrm{C}, 1900^{\circ} \mathrm{C} ; \mathrm{b} 1.3 \mathrm{C}, 2000^{\circ} \mathrm{C}$

As shown in Fig. 2 a that carbon content was 1.3 times, the reduction temperature was $1900^{\circ} \mathrm{C}$, heat preservation for 30 minutes, $\mathrm{Al}_{4} \mathrm{C}_{3}, \mathrm{Al}_{13} \mathrm{Fe}_{4}, \mathrm{Al}_{4} \mathrm{SiC}_{4}, \mathrm{SiC}, \mathrm{Si}$ and $\mathrm{Al}$ were generated by carbon reduction coal fly ash and $\mathrm{Al}_{2} \mathrm{O}_{3}$ was unreacted. It can be seen from $b$ in Fig. 2 that when the carbon content was 1.3 times, the reduction temperature was $2000^{\circ} \mathrm{C}$ and the temperature was maintained for 30 minutes, the products of carbon reduction coal fly ash were $\mathrm{Al}_{2} \mathrm{Fe}, \mathrm{Al}_{8} \mathrm{Fe}_{2} \mathrm{Si}, \mathrm{Al}_{4.5} \mathrm{FeSi}$, $\mathrm{Al}_{2} \mathrm{OC}, \mathrm{SiC}$, Si and Al. Comparing a and b in Fig.2, when carbon content was 1.3 times and reduction temperature was kept for 30 minutes at $1900^{\circ} \mathrm{C}$, reduction products by carbon reduction coal fly ash were $\mathrm{Al}_{4} \mathrm{C}_{3}, \mathrm{Al}_{4} \mathrm{SiC}_{4}$, it was not conducive to the formation of $\mathrm{Al}$ and $\mathrm{Si}$. There was no $\mathrm{Al}_{4} \mathrm{C}_{3}$ or $\mathrm{Al}_{4} \mathrm{SiC}_{4}$ in the reduction products by carbon reduction coal fly ash at $2000^{\circ} \mathrm{C}$, the peak intensity of $\mathrm{SiC}$ was decreased and the peak intensity of $\mathrm{Al}$ was increased, which was more effective than the reduction product at $1900^{\circ} \mathrm{C}$.

\section{Effect of carbon content on preparation of silicon-aluminum alloy from carbon reduction coal} fly ash.

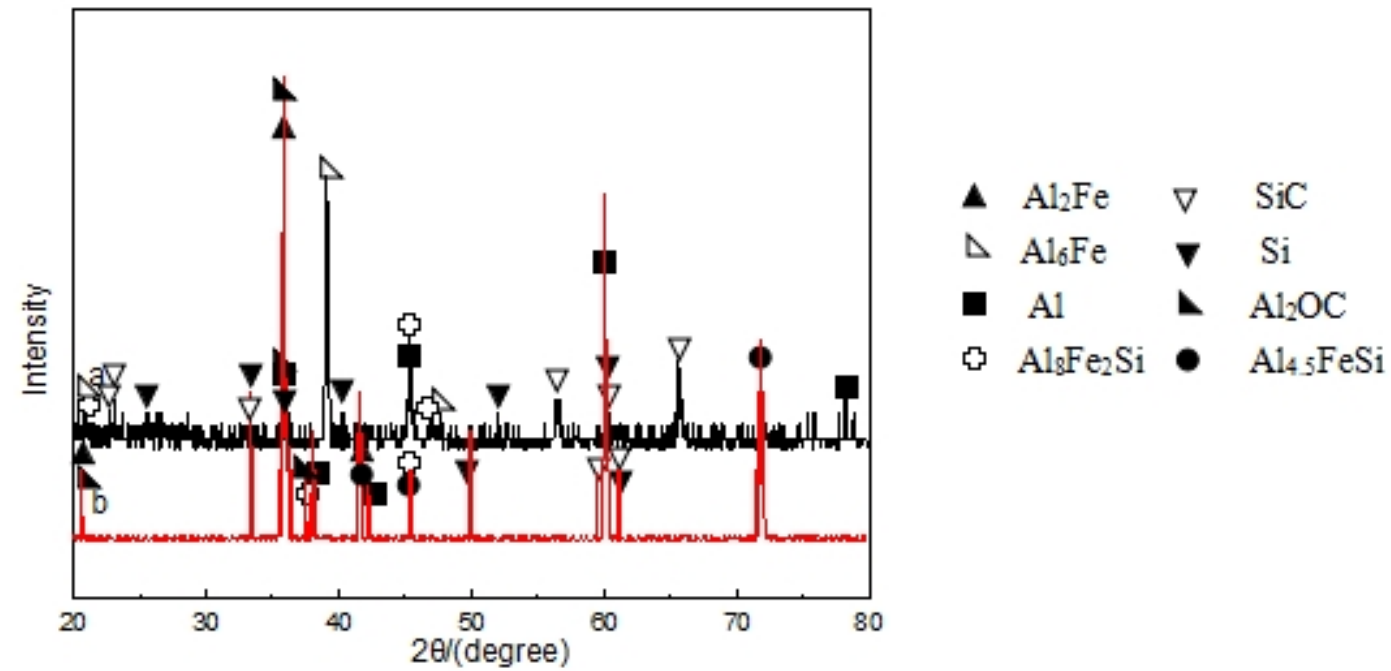

Fig. 3 XRD pattern of the reduced product a $1.15 \mathrm{C}, 2000^{\circ} \mathrm{C}$; b $1.3 \mathrm{C}, 2000^{\circ} \mathrm{C}$ 
It can be seen from a in Fig. 3 that when carbon content was 1.15 times, reduction temperature was $2000^{\circ} \mathrm{C}$ and heat preservation for 30 minutes, $\mathrm{Al}_{6} \mathrm{Fe}, \mathrm{Al}_{8} \mathrm{Fe}_{2} \mathrm{Si}, \mathrm{SiC}, \mathrm{Si}$ and $\mathrm{Al}$ were generated by carbon reduction coal fly ash. As shown in Fig.3 b, when the amount of carbon was 1.3 times, reduction temperature was $2000^{\circ} \mathrm{C}$ and heat preservation was 30 minutes, $\mathrm{Al}_{2} \mathrm{Fe}, \mathrm{Al}_{8} \mathrm{Fe} 2 \mathrm{Si}_{1} \mathrm{Al}_{4.5} \mathrm{FeSi}$, $\mathrm{Al}_{2} \mathrm{OC}, \mathrm{SiC}, \mathrm{Si}$ and $\mathrm{Al}$ were formed by carbon reduction coal fly ash. Compared with $\mathrm{a}$ and $\mathrm{b}$ in Fig.3, when the carbon content was 1.3 times, there were more kinds of reduction products and more impurities. Therefore, when reduction temperature was $2000^{\circ} \mathrm{C}$, heat preservation for 30 minutes and the carbon content was 1.15 times, the effect of carbon reduction coal fly ash to prepare $\mathrm{Si}-\mathrm{Al}$ alloy was better.

\section{Conclusions}

In high frequency induction melting furnace, coal-fired power plant coal fly ash was used as the raw material, charcoal was used as the reducing agent, the wood calcium was used as the binder and samples were prepared by adding water. Under the condition of different reduction temperature and different carbon content, the preparation of silicon-aluminum alloy by carbothermal reduction coal fly ash was studied. The reduction products were characterized by XRD. The results showed that under the conditions of carbon content was 1.15 times and reduction temperature was $1900^{\circ} \mathrm{C}$, the products of carbon reduction coal fly ash were $\mathrm{Al}_{4} \mathrm{C}_{3}, \mathrm{Al}_{2} \mathrm{Fe}, \mathrm{Al}_{13} \mathrm{Fe}_{4}, \mathrm{Al}_{4.5} \mathrm{FeSi}, \mathrm{SiC}, \mathrm{Si}, \mathrm{Al}$ and unreacted $\mathrm{Al}_{2} \mathrm{O}_{3}$. When carbon content was 1.15 times and reduction temperature was $2000^{\circ} \mathrm{C}$, the reduction products were $\mathrm{Al}_{6} \mathrm{Fe}, \mathrm{Al}_{8} \mathrm{Fe}_{2} \mathrm{Si}, \mathrm{SiC}, \mathrm{Si}$ and $\mathrm{Al}$; silicon-aluminum alloy was obtained. When carbon content was 1.3 times and reduction temperature was $1900^{\circ} \mathrm{C}$, the reduction products were $\mathrm{Al}_{4} \mathrm{C}_{3}, \mathrm{Al}_{13} \mathrm{Fe}_{4}, \mathrm{Al}_{4} \mathrm{SiC}_{4}, \mathrm{SiC}, \mathrm{Si}, \mathrm{Al}$, and unreacted $\mathrm{Al}_{2} \mathrm{O}_{3}$. When carbon content was 1.3 times and reduction temperature was $2000^{\circ} \mathrm{C}$,reduction products had many impurities. In this study, when carbon content was 1.15 times and reduction temperature was $2000^{\circ} \mathrm{C}$, silicon-aluminum alloy was obtained, impurities of the reduction products were less, the effect of carbon reduction coal fly ash on the preparation of silicon-aluminum alloy was the best.

\section{Acknowledgments}

This work was financially supported by the Guizhou Provincial Science and Technology Foundation(No.[2014]7460), Guizhou Provincial Ordinary College Innovation Team of Coal Solid Waste Recycling Technology, No.[2014]46,Guizhou province ordinary college innovation team of mineral processing and comprehensive utilization of scientific and technological (No.[2015]69), the Guizhou provincial department of education fund project (QianjiaoheKYzi[2016]102) and Solid Waste Recycling Laboratory of Coal Utilization(No.2011-278).

\section{References}

[1]Dabing,Yang, Huaqiang,Yao,Guojun,Ma,et al: Recyclable Resources and Circular Economy Vol. 4(2011),p.33-36.

[2]Xie Keqiang,Liu Ziliang,Ma Wenhui,et al:J.Kunming Uni.Sci.Techno.( Natural Science Edition) Vol.40(2015),p.1-7.

[3] Y.L.Saraswathi,S.Das,D.P.Mondal:Mater.Sci.Eng A.Vol.3(2006),p.11-21.

[4]Zhang Xianfu: Ferror-Alloys Vol.5(2005),p.12-15.

[5]Ziyong Li,Chunhan Wu,Qingchun Yu,et al:J.Chin. Coal Soc.Vol.41(2016),p.769-775. 